\title{
Competence of human resources, quality of information technology, organizational commitment and successful implementation of accrual-based accounting
}

\author{
La Ode Anto ${ }^{a *}$, Wa Ode Aswatia ${ }^{\text {and Hasnita }}$
}

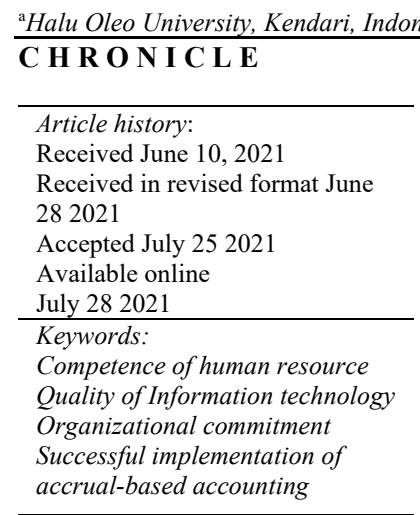

\begin{abstract}
A B S T R A C T
This study aims to determine the effect of competence of human resource, quality of information technology and organizational commitment on the successful implementation of accrual-based accounting. The sample in this study was 56 respondents who were obtained using purposive sampling technique from employees of the administration and accounting department of the Regional Finance and Assets Agency of Kendari City. The analytical method used is descriptive analysis method and multiple linear regression. The results showed that the competence of human resources, the quality of information technology and organizational commitment have a positive and significant impact on the successful implementation of accrual-based accounting in local governments. This shows that the higher the level of competence of human resources, the quality of information technology and organizational commitment, the successful implementation of accrual-based accounting in local governments will be better.
\end{abstract}

(C) 2022 Growing Science Ltd. All rights reserved.

\section{Introduction}

The accounting system applied to public organizations (public sector accounting) is constantly evolving in accordance with the dynamics of its environment. In the past, the public sector has been affected by the introduction of significant reforms in the public accounting system in an international context with the aim of improving the management and decision-making of government agencies (Christiaens, et al., 2010). One part of the reform of the public accounting system is the reform of the government accounting system, namely the change from cash accounting basis to accrual accounting basis. With this change, it is hoped that it will increase transparency and accountability in the management and reporting of government finances and follow international best practices that are adapted to the conditions of each country. The purpose of government financial reporting is to provide information that is useful for decision making, and to demonstrate the reporting entity's accountability for the resources entrusted to it. Financial statements present information about the financial position, budget realization, budget balance, cash flow, operating results and changes in equity of a reporting entity that is useful for users in evaluating decisions regarding resource allocation (Mahmudi, 2011: 276). The Regional Government Financial Report is one form of regional government financial accountability made by the regional head. Initially, the Indonesian government had compiled Government Accounting Standards based on Cash Toward Accrual. Furthermore, the Government applies the Accrual-Based Government Accounting Standards by issuing Government Regulation No. 71 of 2010. The purpose of implementing accrual-based accounting is not only to fulfill the mandate of the law but also to meet international standards for preparing financial statements based on the International Public Sector Accounting Standards (IPSAS). It is hoped that the Regional Government Financial Reports are on par with international financial reports.

* Corresponding author

E-mail address: laodeanto@gmail.com (L. O. Anto)

(C) 2022 Growing Science Ltd. All rights reserved. doi: 10.5267/j.ac.2021.7.008 
Accrual-based accounting is considered better than cash basis, because accrual-based accounting is believed to be able to produce financial statements that are more reliable, more accurate, comprehensive, and relevant for economic, social and political decision making (Tengku, 2015). In Study No. 14 published by the International Public Sector Accounting Standards Board (2011), says that the information presented on accrual-based accounting in financial reporting allows users to: 1) Assess accountability for the management of all entity resources and the distribution of these resources, 2) Assess performance, financial position and cash flows of an entity, and 3) Making decisions about providing resources, or doing business with an entity. In practice, local governments find many difficulties in understanding accrual-based government accounting standards and their implementation in the preparation of local government financial reports. The government also faces several obstacles including the lack of quality human resources, information technology, and organizational commitment that has not met the predetermined plans. The results of the examination by the Supreme Audit Agency of the Republic of Indonesia on 541 Regional Government Financial Reports in Indonesia in 2018 showed that Unqualified Opinion for 485 Financial Statements (89,65\%), Qualified Opinion for 50 Financial Statements (9,24\%), and Disclaimer of Opinion for 6 Financial Statements (1,11\%) (Financial Audit Board of the Republic of Indonesia, 2019).

Many studies have been carried out on the implementation of accrual-based accounting in various countries (Phuong, et al., 2020; Fuchs, et al., 2015; Leppänen \& Näsi, 2015; Azmi \& Mohamed, 2014; Antipova \& Bourmistrov, 2013; Rahmansah, 2012; Kara \& Kilic, 2011). Phuong et al. (2020) suggest that there are several factors that influence the reform of the public sector accounting system to an accrual-based accounting system, namely accounting staff - especially their expertise, competence, and work experience; training and support of the consulting experts; costs of the accounting reform; level of information technology application; funding and assistance from international organizations; legal environment. Rahmansah (2012) also suggests that the factors that greatly influence the success of the implementation of accrual-based government accounting standards are distinguished by factors that can be controlled and factors that cannot be controlled by local governments. Factors that can be controlled are organizational commitment, human resources and supporting tools. While the factors that cannot be controlled by local governments are government regulations or regulations that occur so quickly. Furthermore, Karyogis and Putra (2017) argue that the success of implementing accrualbased accounting standards in local governments is largely determined by the level of competence of human resources, organizational commitment, and the use of information technology. In addition, the successful implementation of accrualbased government accounting standards is also influenced by the leadership style, communication, and internal control system. There are many studies on the factors that influence the successful implementation of accrual-based accounting standards in local governments, but the results are still inconsistent and contradictory.

The results of the research by Dewi and Handayani (2018) found that the competence of human resources has a positive and significant effect on the success of the implementation of accrual-based government accounting standards in local governments. This finding is in line with the results of research by Arih, et al. (2017), Dewi, et al. (2017), Slamet (2016), Putra and Aryanto (2015), and Kristiawati (2015). However, this finding is not in line with the results of the study by Jantong, et al. (2018), Marsdenia and Arthaingan (2016), and Sampel, et al. (2014) who found that human resource competence had a negative and insignificant effect on the successful implementation of accrual-based accounting standards. Furthermore, the results of research by Arif (2020), Safitri (2017), Arif, et al. (2017), Slamet (2016), and Kristoyo, et al. (2013) found that the quality of information technology has a positive and significant effect on the successful implementation of accrual-based accounting standards in local governments. This finding is not in line with the results of research conducted by Hasibuan (2021), Jantong, et al. (2018), and Marsdenia and Arthaingan (2016) who found that the quality of information technology had no significant effect on the successful implementation of accrual-based government accounting standards. Another contradiction can be seen from the research results of Arif (2020), Safitri (2017), Jalardi and Riharjo (2016), Putra and Ariyanto (2015), Azman (2015), Adventana and Kurniawan (2013), and Pratiwi, et al. (2013) who found that organizational commitment had a positive and significant effect on the successful implementation of accrual-based government accounting standards in local governments. This finding is not in line with the results of research conducted by Rahmansah (2012) who found that organizational commitment has no significant effect on the successful implementation of accrual-based government accounting standards in local governments.

Based on the phenomena and gaps of previous research, this study tries to fill these gaps. This study also develops research that has been done previously that examines the factors that influence the successful implementation of accrual-based government accounting standards in the preparation of local government financial statements.

\section{Literature review}

\subsection{New Public Management (NPM)}

New Public Management (NPM) is the most current public administration management system in the world and is being realized in almost all countries. NPM is a decentralized management system with new management tools such as controlling, benchmarking and clean management. NPM is also understood as privatization as far as possible of government activities. The aim of NPM is to change public administration in such a way that, even if it is not yet a company, it can be more like a company. Public administration as a service provider for citizens must be aware of its duty to produce efficient and effective 
services. But, on the other hand it should not be profit-oriented. Osborne and Gaebler (1992) suggest that the goal of NPM is to change administration in such a way that public administration as a service provider for the community must be aware of its duty to produce efficient and effective services, but not profit-oriented. Accounting reform is an important part of NPM and is the first stage of government reform, followed by reform of government management, organizations, and other parts of public administration (Christiaens, 1999). Furthermore, the practice of the traditional cash-based accounting system is also starting to be abandoned by gradually implementing the accrual accounting system. This change is a consequence of the gap in trust in the implementation of traditional management techniques in public sector organizations and the increasing trust in management instruments used in private sector organizations. The implication of adopting the NPM model is the need for several reforms in the public sector, such as accounting and budgeting reforms, financial management reforms, and audit reforms as institutional reforms (Robinson, 1998). In connection with this, McKendrick (2007) suggests that accrualbased accounting spreads to various countries in line with the development of the implementation of the NPM concept. This is a part of the adoption of private sector management processes and techniques to public sector management.

\subsection{Accrual-Based Accounting}

The purpose of government accounting is in the context of accountability, managerial, and supervision (Halim, et al., 2012). The accrual-based Government Accounting Standard is a guide for central and local government officials in accounting for and reporting the receipt and use of funds in a transparent and accountable manner (Dewi and Handayani, 2018). Accrualbased accounting is considered better than cash basis, because accrual-based accounting is believed to be able to produce financial statements that are more reliable, more accurate, comprehensive, and relevant for economic, social and political decision making (Tengku, 2015). The accrual basis is an accounting basis where economic transactions or accounting events are recognized, recorded, and presented in the financial statements based on the effect of the transaction at the time the transaction occurs, regardless of when cash is received or paid. The implementation of accrual-based accounting in the government is based on Government Regulation Number 71 of 2010 concerning Accrual-Based Government Accounting Standards, consisting of Statement of Government Accounting Standards: Number 01 concerning the Presentation of Financial Statements; Number 02 concerning Budget Realization; Number 03 concerning Cash Flow Statements; Number 04 concerning Notes on Financial Statements; Number 05 concerning Accounting for Inventory; Number 06 concerning Investment Accounting; Number 07 concerning Fixed Assets; Number 08 concerning Accounting for Construction in Works; Number 09 concerning Accounting for Liabilities; Number 10 concerning Correction of Errors; Number 11 concerning Accounting for Consolidated Financial Statements; and Number 12 concerning Operational Reports.

\subsection{Competence of human resources}

Human resources are a very important component that cannot even be separated from an organization. Human resources are the key that determines the development of an organization (Dewi and Handayani, 2018). In essence, human resources in the form of humans who are employed in an organization as movers, thinkers and planners in an organization to achieve the goals of the organization. Human resources are the only resources that have feelings, desires, skills, knowledge, encouragement, power, and work (ratio, taste and intention). All of these potentials affect the organization's efforts to achieve goals (Arif, 2020). The use of the accrual basis is one of the characteristics of modern financial management practices in the public sector which aims to provide more transparent information. However, in reality the implementation of the accrual-based accounting system still has many obstacles in the human resource sector (Suryanto, 2017). The preparation of accrual-based local government financial reports requires competent human resources who understand government accounting. Competence shows the characteristics of knowledge and skills possessed by each individual that enable them to carry out their duties and responsibilities actively and raise professional quality standards in their work. The role of universities and professional organizations is very important to meet the need for competent human resources in the field of government accounting (Grandis and Mattei, 2012). Human resource competency indicators consist of training, skills, attitudes and knowledge. Competence is a combination of knowledge, skills and abilities in a particular career field that allows a person to perform tasks or functions including in the preparation of financial statements (Arih, et al., 2017).

\subsection{Quality of information technology}

Reform of the accounting system in the government requires the development of adequate information technology to produce reliable and transparent financial reports. The government accounting system is a series of manual or computerized procedures ranging from data collection, recording, summarization, to reporting of financial position and government financial operations. The government accounting system always requires the government to keep up with the times, so that in carrying out it requires information technology to help the government accounting system run smoothly (Dewi and Handayani, 2018). The government needs to improve information technology systems and administrative procedures to ensure that accounting data can be obtained in a timely, complete, and accurate manner (Biswas, et al., 2015). According to Sudaryati and Heriningsih (2014) information technology is the availability of devices that assist human resources in carrying out tasks such as the availability of computers and software that assist in the preparation of local government financial reports. Seeing the complexity of the implementation of accrual-based accounting, it is certain that its implementation in a government environment requires a more complicated accounting system and information technology. Adequate quality of information technology will greatly support the implementation of accrual-based accounting. The 
quality of information technology can be seen from the quality of hardware components, software, access speed, and quality of users. Information technology is a combination of computer technology and communication technology (Supra, 2016). According to Jantong (2017) the availability of information technology basically provides convenience in the process of carrying out work, so that it can increase productivity and create a sense of comfort for interested people. Furthermore, Jalardi and Riharjo (2016) say that information technology is a tool to support the success of a process of achieving the vision and mission, because if information technology is not available then all activities carried out will not achieve the expected results according to the plan. The availability of the right information technology will be able to support the realization of an effective implementation of Accrual-Based Government Accounting Standards and can improve the quality of government financial reports.

\subsection{Organizational Commitment}

Organizational commitment is a condition in which an individual sides with the organization and its goals and desires to maintain membership in the organization (Robbins, 2008). Organizational commitment is a more concrete form of loyalty that can be seen from the extent to which employees devote attention, ideas, and responsibilities to achieve organizational goals. Organizational commitment is the degree to which employees believe and are willing to accept the goals of the organization and will remain and will not leave the organization. Organizational commitment is an encouragement from within the individual/group to do something to support the success of the organization in accordance with the goals set and prioritize the interests of the organization rather than the interests of individuals or groups (Norfalizah, 2015). In local government, officials who have a high organizational commitment will use the information they have for the benefit of the organization. High organizational commitment from local governments will have an impact on commitment to responsibility for the preparation and presentation of financial statements (Jalardi \& Riharjo, 2016). Furthermore, Karyogis and Putra (2017) stated that changing the habit of recording cash-based transactions into recording accrual-based transactions is not easy, so it requires a strong commitment from every element of the organization to make changes to employee performance to implement accrual basis accounting effectively and efficiently. It takes a high commitment from each individual to implement accrual-based accounting as part of the local government's efforts to achieve accountability and transparency in regional financial management. Commitment can be seen from three indicators, namely affective commitment, ongoing commitment, and normative commitment. Therefore, organizational commitment is a high effort for the organization and acceptance of the values and goals of the organization (Jantong, 2017). Based on the theoretical description above, the conceptual framework of this research can be described as follows:

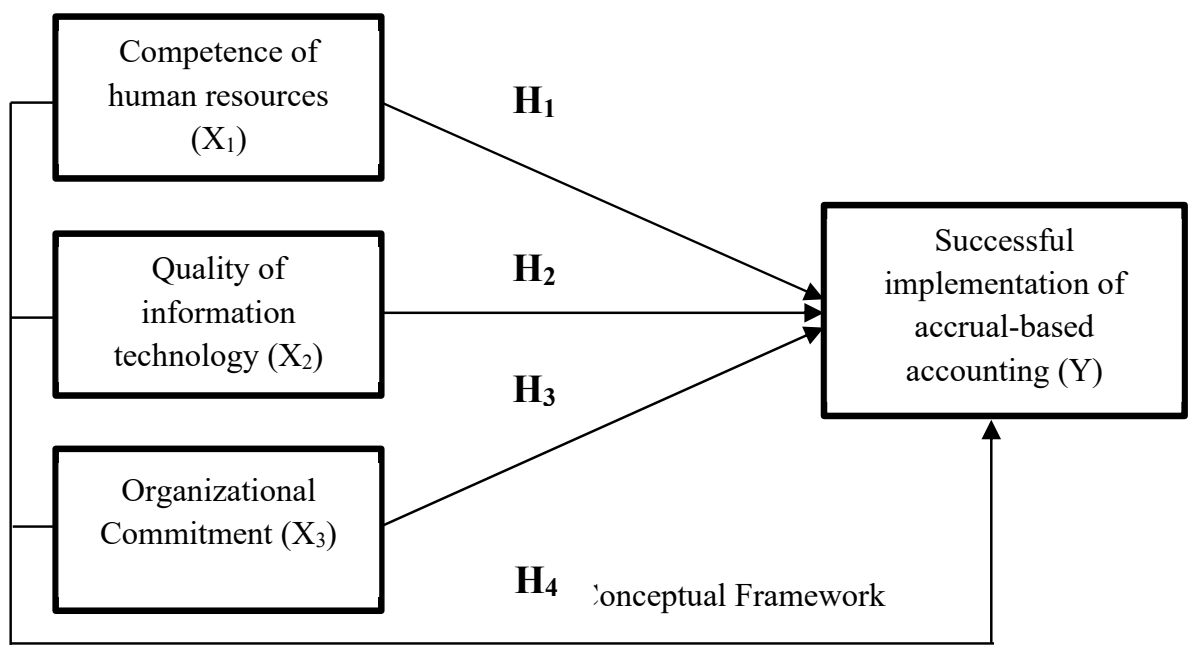

\subsection{Research Hypothesis}

Human resource competence is one of the important components in implementing accrual-based accounting. Competent human resources are indispensable in the preparation of financial statements. The higher the level of competence of human resources in the government sector, the success rate in implementing accrual-based government accounting standards will be more effective. The results of Hasibuan's research (2021) found that the quality of human resources has a positive and significant effect on the success of the implementation of accrual-based government accounting standards. The results of this study are in line with research conducted by Arif (2020), Dewi and Handayani (2018), Dewi, et al. (2017), Arih, et al. (2017), Slamet (2016) and Widyastuti, et al. (2015) which concludes that the quality of human resources has a positive and significant effect on the implementation of the accrual-based government accounting system. However, these findings are not in line with the results of research conducted by Jantong, et al. (2018), Marsdenia and Arthaingan (2016), and Sampel, et al. (2014) which concludes that human resource competence has no significant effect on the implementation of accrualbased government accounting standards in local governments. Based on this description, the following hypothesis is formulated: 
$\mathbf{H}_{1}$ : Human resource competence has a positive and significant effect on the successful implementation of accrual-based accounting.

Information technology is a medium used to speed up the processing of transaction data and the presentation of financial statements. The decision to use the accrual accounting system has consequences for the commitment to provide an integrated accounting system technology. The better the quality of information technology in the government sector, the implementation of accrual-based accounting in local governments will be better. The results of Arif's research (2020) found that the use of information technology had a positive and significant effect on the implementation of accrual-based government accounting standards in the local government environment. The results of this study are in line with the results of research conducted by Dewi and Handayani (2018), Karyogis and Putra (2017), Arih, et al. (2017), Safitri (2017), Slamet (2016), Kristiawati (2015), and Kristoyo, et al. (2013) who concluded that the use of information technology had a positive and significant effect on the successful implementation of accrual-based accounting in local governments. Different results were found by Hasibuan (2021), Marsdenia and Arthaingan (2016), and Runuba, et al. (2013) who concluded that information technology has no significant effect on the successful implementation of accrual-based government accounting standards. Based on this description, the following hypothesis is formulated:

$\mathbf{H}_{2}$ : The quality of information technology has a positive and significant effect on the successful implementation of accrualbased accounting.

High organizational commitment from the local government will have an impact on the commitment to be responsible for the preparation and presentation of financial statements. One of the causes of weakness in the preparation of local government financial reports is the lack of leadership commitment. The stronger the commitment of the regional financial management apparatus to implement a regulation, it will influence improving the quality of financial reports. The results of research conducted by Jantong (2017) found that organizational commitment has a positive and significant effect on the implementation of accrual-based accounting standards in local governments. The results of this study are in line with the results of research conducted by Karyogis and Putra (2017), Safitri (2017), Slamet (2016), Marsdenia and Arthaingan (2016), Jalardi and Riharjo (2016), Azman (2015), Kristiawati (2015), Putra and Aryanto (2015), Adventana and Kurniawan (2013), and Pratiwi, et al. (2013) who concluded that organizational commitment has a significant positive effect on the successful implementation of accrual-based government accounting standards in local governments. In contrast to the research results of Rahmansah (2012) which found that commitment had no effect on the successful implementation of accrual-based government accounting standards in local governments. Based on this description, the following hypothesis is formulated:

\section{$\mathbf{H}_{3}$ : Organizational commitment has a positive and significant effect on the successful implementation of accrual-based accounting.}

The success or failure of the implementation of accrual-based accounting in government organizations cannot be separated from the role of employees as resources who have reason, feelings, desires, skills, and knowledge. The successful implementation of accrual-based accounting in government organizations is also supported by the quality of information technology. The complexity in implementing the accrual basis requires an integrated system and is supported by adequate quality of information technology and the commitment of employees will strengthen their love for the organization so that the implementation of accrual-based accounting can be successful. The results of Karyogis and Putra's research (2017) conclude that human resource competence, organizational commitment, and the use of information technology simultaneously have a positive and significant effect on the successful implementation of accrual-based accounting in local governments. The results of this study are in line with the results of research by Arif (2020), Dewi and Handayani (2018) and Arih, et al. (2017) which concludes that human resource competence, organizational commitment, and information technology simultaneously have a positive and significant effect on the implementation of accrual-based accounting standards in local governments. Based on this description, the following hypothesis is formulated:

H4: Competence of human resources, quality of information technology and organizational commitment have a positive and significant effect on the successful implementation of accrual-based accounting.

\section{Research method}

The population of this study were all employees of the Regional Finance and Assets Agency of Kendari City. By using purposive sampling, obtained a sample of 56 employees in the administration and accounting. The type of data used in this study is primary data, namely data sourced from respondents who were collected through questionnaires using a Likert scale. The data analysis techniques used are descriptive analysis and multiple linear regression analysis using IBM SPSS Version 22 Software with the following regression equation:

Description:

$$
Y=\alpha+b_{1} X_{1}+b_{2} X_{2}+b_{3} X_{3}+e
$$


$\mathrm{Y}=$ Successful implementation of accrual-based accounting

$\alpha=$ Constant

$\mathrm{X}_{1}=$ Competency of human resources

$\mathrm{X}_{2}=$ Quality of information technology

$\mathrm{X}_{3}=$ Organizational commitment

$\mathrm{e}=$ Standard error

Hypothesis testing is done through the $\mathrm{F}$ statistic test, the $\mathrm{t}$ statistic test and the coefficient of determination test. Testing can be done after the regression model is free from the symptoms of classical assumptions. Classical assumption testing conducted in this study included normality test, multicollinearity test, and heteroscedasticity test.

\section{Results and discussion}

\subsection{Descriptive Analysis}

Based on the answers to the questionnaire from the respondents, the following results were obtained:

1. Respondents' responses to the competence of human resources variable are on average 4,60 and fall into the very good category. From the respondent's perception it appears that the knowledge indicator has a higher average respondent's answer compared to other indicators such as training, skills, and attitudes.

2. Respondents' responses to the quality of information technology variable are on average 4,32 and fall into the very good category. From the respondent's perception, it appears that the access speed indicator has a higher average respondent's answer than other indicators such as hardware quality, software quality, and human/user quality.

3. Respondents' responses to the organizational commitment variable were on average 4,35 and were included in the very good category. From the respondent's perception, it appears that the normative commitment indicator has a higher average respondent's answer compared to other indicators such as affective commitment and ongoing commitment.

4. Respondents' responses to the successful implementation of accrual-based accounting variable are on average 4,22 and fall into the very good category. From the respondent's perception, it appears that the indicator of Government Accounting Standard Statement No. 04 concerning Notes to financial statements has a higher average respondent's answer compared to other indicators.

The results of the correlation coefficient and Cronbach alpha to test the validity and reliability of the use of statement items from variable indicators are explained as follows:

1. Based on the results of the validity test, it was found that the variables of human resource competence, information technology quality, and organizational commitment have a Pearson correlation $>0,30$ and all question items have met the validity requirements.

2. Based on the results of the reliability test, it shows that the Cronbach alpha value of the four research variables has a value above or greater equal to $0,60(=0,60)$. Thus it can be concluded that the statements in the questionnaire are valid and reliable statements.

\subsection{Classic assumption test}

Classical assumption test is a test conducted to assess whether in the regression model there is a problem with classical assumptions. To produce an unbiased and best regression model, several classical assumptions must be met. To detect the existence of multicollinearity in the regression model, it can be seen from the relationship between the independent variables which is shown by the tolerance number and the variance inflation factor (VIF). Is the tolerance number $>0,10$ and VIF $<$ 10 , it indicates that there is no multicollinearity in the regression model as shown in the following table:

Table 1

Summary of Multicollinearity Test Results

\begin{tabular}{cccc}
\hline Variabel & Tolerance & VIF & Description \\
\hline Equation 1 & 0.975 & 1.026 & Non \\
Equation 2 & 0.513 & 1.949 & Multicollinearity \\
Equation 3 & & & Multicollinearity \\
Non & Multicollinearity \\
\hline
\end{tabular}

Table 1 shows that the tolerance number for each variable in this study is 0,$975 ; 0,513$ and 0,522 or is above 0,10 and the VIF value is 1,$026 ; 1,949$ and 1,916 or below 10 . This indicates that there is no correlation between the independent variables, so it can be concluded that there is no multicollinearity.

Heteroscedasticity test was carried out through a scatterplot. Homoscedasticity of the independent variable to the dependent variable is fulfilled if the residual value and the predicted value do not form a certain pattern and move away from the 0 scale number. The results of data analysis show the resulting scatter diagram as follows: 
From the scatterplot graph above, it can be seen that the points spread randomly and are spread both above and below the number 0 on the $\mathrm{Y}$ axis. It can be concluded that there is no heteroscedasticity in the regression model, so the regression model is feasible to use to predict the successful implementation. of accrual-based accounting based on the input of the independent variables Competence of human resources $\left(\mathrm{X}_{1}\right)$, Quality of information technology $\left(\mathrm{X}_{2}\right)$ and organizational commitment $\left(\mathrm{X}_{3}\right)$. The normality test was conducted to determine whether in the regression model, the dependent variable and the independent variable were normally distributed or not. To test this normality, it can be seen from the display of the Normal Probability Plot graph.

Scatterplot

Dependent Variable: Successful Implementation of Accrual-Based Accounting

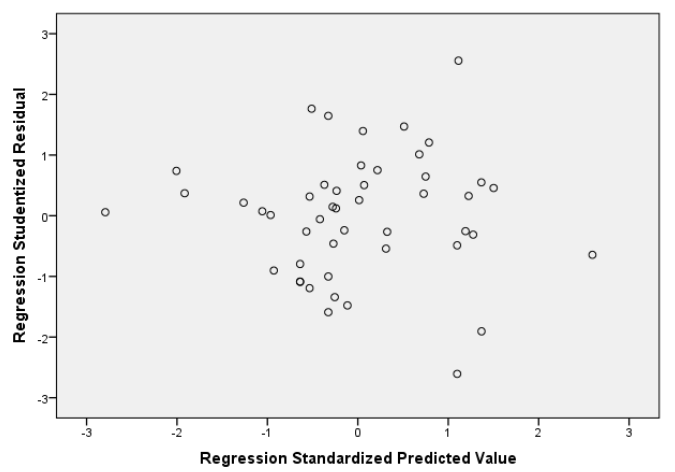

Fig. 2. Heteroscedasticity Test Results - Scatterplot Graph

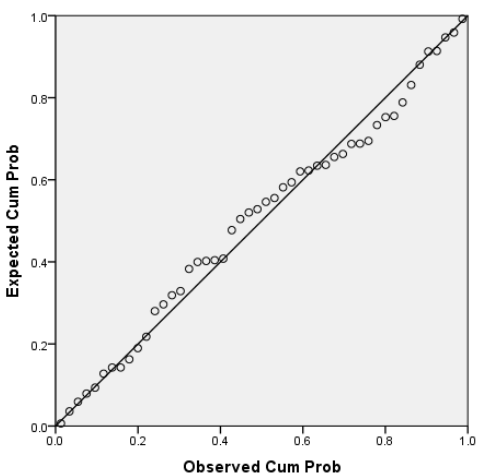

Fig. 3. Normality Test Results-Normal Probability Plot Graph

In the normal probability plot graph above, it can be seen that the points spread around the diagonal line, and their distribution follows the direction of the diagonal line. Thus the regression model has met the assumption of normality.

\subsection{Multiple Linear Regression Analysis}

The results of multiple regression analysis processed using IBM SPSS Version 22 Software obtained values as follows:

Table 2

Multiple Linear Regression Test Results

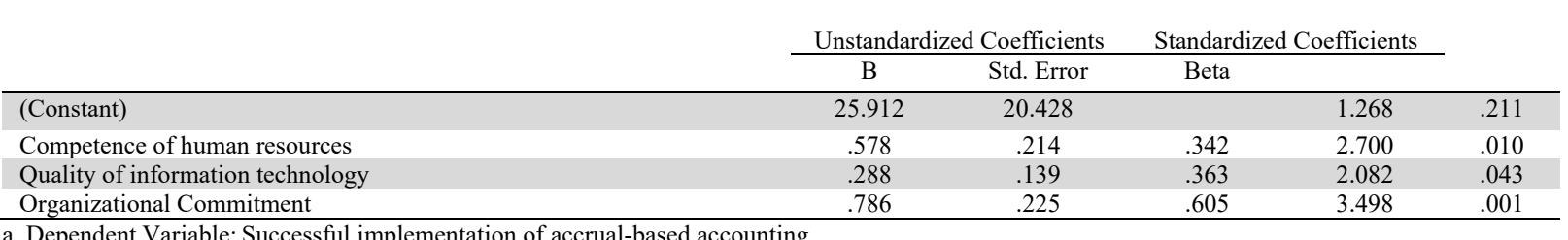

a. Dependent Variable: Successful implementation of accrual-based accounting

The results of testing the influence of human resource competence, the quality of information technology and organizational commitment to the successful implementation of accrual-based accounting can be expressed in multiple linear regression equations as follows:

$$
\mathrm{Y}=25.912+0.578 \mathrm{X}_{1}+0.288 \mathrm{X}_{2}+0.786 \mathrm{X}_{3}+\varepsilon
$$

The multiple linear regression equation model above can be described as follows:

1. The constant value of 25.912 states that if the independent variable is considered constant or zero, the successful implementation of accrual-based accounting will be 25.912 .

2. The regression coefficient of the human resource competency variable $\left(\mathrm{X}_{1}\right)$ of 0.578 indicates that each increase of one unit of the human resource competency variable will increase the successful implementation of accrual-based accounting by 0.578 .

3. The regression coefficient of the information technology quality variable $\left(\mathrm{X}^{2}\right)$ of 0.288 indicates that each increase of one unit of the information technology quality variable will affect the successful implementation of accrual-based accounting by 0.288 .

4. The regression coefficient for organizational commitment variable $\left(\mathrm{X}_{3}\right)$ of 0.786 indicates that each increase of one unit of organizational commitment variable will increase the successful implementation of accrual-based accounting by 


\subsection{Hypothesis test}

Partial Test ( $t$ Test)

The test was conducted to determine the effect of each independent variable partially on the dependent variable. Hypothesis testing can be done with the following criteria: If the significance probability $>0,05$ or $\mathrm{t}_{\text {-count }}<\mathrm{t}$-table then $\mathrm{H}_{0}$ is accepted and $\mathrm{H}_{\mathrm{a}}$ is rejected, and if the significance probability is $<0,05$ or $\mathrm{t}$-count $>\mathrm{t}$-table then $\mathrm{H}_{0}$ is rejected and $\mathrm{H}_{\mathrm{a}}$ is accepted. The results of multiple linear regression as shown in Table 2. The first hypothesis $\left(\mathrm{H}_{1}\right)$ states that the competence of human resources has a positive and significant effect on the successful implementation of accrual-based accounting. Based on the test results, the significance value for the effect of $\mathrm{X}_{1}$ on $\mathrm{Y}$ is $0,010<0,05$ and $\mathrm{t}$-count $2,700>\mathrm{t}$-table 2,015 then $\mathrm{H}_{0}$ is rejected and $\mathrm{H}_{\mathrm{a}}$ is accepted, so it can be concluded that $\mathrm{H}_{1}$ is accepted, meaning that there is a positive and significant influence of the competence of human resources on successful implementation of accrual-based accounting. The second hypothesis $\left(\mathrm{H}_{2}\right)$ states that the quality of information technology has a positive and significant effect on the successful implementation of accrual-based accounting. Based on the test results, the significance value for the effect of $\mathrm{X}_{2}$ on $\mathrm{Y}$ is $0,043<0,05$ and $\mathrm{t}$-count 2,082 > t-table 2,015 then $\mathrm{H}_{0}$ is rejected and $\mathrm{H}_{\mathrm{a}}$ is accepted, so it can be concluded that $\mathrm{H}_{2}$ is accepted, meaning that there is a positive and significant influence of the quality of information technology on the successful implementation of accrualbased accounting. The third hypothesis $\left(\mathrm{H}_{3}\right)$ states that organizational commitment has a positive and significant effect on the successful implementation of accrual-based accounting. Based on the test results, the significance value for the effect of $\mathrm{X}_{3}$ on $\mathrm{Y}$ is $0,001<0,05$ and $\mathrm{t}$-count $3,498>\mathrm{t}$-table 2,015 then $\mathrm{H}_{0}$ is rejected and $\mathrm{H}_{\mathrm{a}}$ is accepted, so it can be concluded that $\mathrm{H}_{3}$ is accepted, meaning that there is a positive and significant influence on organizational commitment to the successful implementation of accrual-based accounting.

\section{Simultaneous Test (F Test)}

The $\mathrm{F}$ test was conducted to determine the effect of the independent variables simultaneously on the dependent variable. Hypothesis testing can be done with the following criteria: If the significance probability $>0,05$ or $\mathrm{F}_{\text {-count }}<\mathrm{F}_{\text {-table }}$ then $\mathrm{H}_{0}$ is accepted and $\mathrm{H}_{\mathrm{a}}$ is rejected, and if the significance probability is $<0,05$ or $\mathrm{F}$-count $>\mathrm{F}$-table then $\mathrm{H}_{0}$ is rejected and $\mathrm{H}_{\mathrm{a}}$ accepted. The results of multiple linear regression testing as shown in the following table.

Table 3

The ANOVA test for multiple linear regression test results

\begin{tabular}{|c|c|c|c|c|c|c|}
\hline \multicolumn{2}{|r|}{ Model } & Sum of Squares & Df & Mean Square & \multirow{2}{*}{$\frac{F}{6.696}$} & \multirow{2}{*}{$\frac{\text { Sig. }}{.001^{\mathrm{b}}}$} \\
\hline 1 & Regression & 240.723 & 3 & 80.241 & & \\
\hline & Residual & 527.257 & 44 & 11.983 & & \\
\hline & Total & 767.979 & 47 & & & \\
\hline
\end{tabular}

a. Dependent Variable: Successful implementation of accrual-based accounting

b. Predictors: (Constant), Competency of human resources, Quality of information technology, Organizational commitment

The fourth hypothesis $\left(\mathrm{H}_{4}\right)$ states that the competence of human resources, the quality of information technology and organizational commitment simultaneously have a positive and significant effect on the successful implementation of accrual-based accounting. Based on the test results, the significance value for the effect of $X_{1}, X_{2}$ and $X_{3}$ simultaneously on $\mathrm{Y}$ is $0.000<0,001$ and the $\mathrm{F}_{\text {-count }}$ value is $6.696>\mathrm{F}_{\text {-table }} 2,580$, then $\mathrm{H}_{0}$ is rejected and $\mathrm{H}_{\mathrm{a}}$ is accepted, so it can be concluded that $\mathrm{H}_{4}$ is accepted means simultaneously there is a positive and significant influence of human resource competence, quality of information technology, and organizational commitment to the successful implementation of accrual-based accounting. The determinant coefficient is intended to determine how far the independent variables, namely the competence of human resources $\left(\mathrm{X}_{1}\right)$, the quality of information technology $\left(\mathrm{X}_{2}\right)$ and organizational commitment $\left(\mathrm{X}_{3}\right)$ affect the successful implementation of accrual-based accounting (Y). The value of $R^{2}$ has an interval between 0 and $1\left(0 \leq R^{2} \leq 1\right)$.

Table 3

Multiple Linear Regression Test Results

\begin{tabular}{|c|c|c|c|c|c|}
\hline Model & $\mathrm{R}$ & R Square & $\begin{array}{c}\text { Adjusted R } \\
\text { Square }\end{array}$ & $\begin{array}{l}\text { Std. Error of } \\
\text { the Estimate }\end{array}$ & $\begin{array}{l}\text { Durbin- } \\
\text { Watson }\end{array}$ \\
\hline 1 & $.550^{\mathrm{a}}$ & .622 & .637 & 1.79483 & $.550^{\mathrm{a}}$ \\
\hline
\end{tabular}

Table 3 shows that the magnitude of $R$ Square $\left(R^{2}\right)$ is 0.622 , this means that $62.2 \%$ of the variables for the successful implementation of accrual-based accounting can be explained by the variables of human resource competence, the quality of information technology, and organizational commitment, while the remaining $37.8 \%$ can be explained by other factors 
that have not been included in the model or were not measured in this study.

\subsection{Discussion}

The Influence of Competence of Human Resources on the Successful Implementation of Accrual-Based Accounting

The results of this study indicate that the competence of human resources has a positive and significant effect on the successful implementation of accrual-based accounting in local governments. This can be interpreted that the better the competence of human resources that contribute to the implementation of the accounting system, the better the successful implementation of accrual-based accounting. Vice versa, the lower the competence of human resources that contribute to the implementation of the accounting system, the lower the success of the implementation of accrual-based accounting in local governments (Dewi and Handayani, 2018). Jantong (2017) suggests that the implementation of accrual-based government accounting standards in local governments is closely related to the availability of human resources. Human resources are the main driver of the operation of an organization, including if there are changes in the organization. If the government apparatus does not have the qualifications and is incompetent in the field of accounting both in terms of education, understanding and experience, then the information presented does not reflect the actual results. Therefore, the competence of human resources plays an important role in the implementation of accrual-based government accounting standards in local governments. The results of this study support the results of research conducted by Hasibuan (2021), Phoung, et al. (2020), Arif (2020), Matekele and Komba (2019), Vezalin, et al. (2019), Dewi and Handayani (2018), Agyemang (2017), Arih, et al. (2017), and Safitri (2017) who show that the competence of human resources has a significant effect on the successful implementation of accrual-based accounting in local governments.

\section{The Effect of Quality of Information Technology on the Successful Implementation of Accrual-Based Accounting}

The results of this study indicate that the quality of information technology has a positive and significant effect on the successful implementation of accrual-based accounting in local governments. This can be interpreted that the higher the quality of information technology used in a system, it will further optimize the successful implementation of accrual-based accounting. The quality of information technology is seen from the speed of computer access in processing financial data quickly and accurately and the ability of information technology to provide the required information in a timely manner. From the point of view of new public management, the government seeks to emphasize more effective and efficient government behavior for the wider public interest. Improving the quality of information technology is a government step to encourage government performance to be more efficient and effective in presenting financial information. By presenting financial information using adequate hardware, software, and networks, it is hoped that reliable financial information can be realized for the benefit of the government and the public. The results of this study are in line with the research of Phoung, et al. (2020), Arif (2020), Vezalin, et al. (2019), Dewi and Handayani (2018), Kamemy, et al. (2017), Arih, et al. (2017), Safitri (2017), Supra (2016), Slamet (2016), Kristiawati (2015), and Kristoyo, et al. (2013) which shows that the quality of information technology has a significant influence on the successful implementation of accrual-based accounting in local governments.

\section{The Effect of Organizational Commitment on the Successful Implementation of Accrual-Based Accounting}

The results of this study indicate that organizational commitment has a positive and significant effect on the successful implementation of accrual-based accounting in local governments. This can be interpreted that the higher the organizational commitment of the local government, the success of the implementation of accrual-based accounting will also be higher. Likewise, if the organizational commitment is low, the success of accrual-based accounting implementation will also be low. A strong commitment will allow a person to be able to do tasks quickly and precisely, but on the contrary without commitment, big work will be difficult to carry out. In local governments, officials who have a high organizational commitment will use the information they have to complete their tasks relatively more precisely. With a high organizational commitment, he will have an attitude of loyalty and desire to achieve his organizational goals well (Dewi and Handayani, 2018). This is in line with research conducted by Arif (2020), Vezalin, et al. (2019), Karyogis and Putra (2017), Jantong (2017), Safitri (2017), Marsdenia and Arthaingan (2016), Satrio, et al. (2016), Jalardi and Riharjo (2016), Putra and Aryanto (2015), Azman (2015), Kristiawati (2015), Adventura and Kurniawan (2013), Pratiwi, et al. (2013) which shows that organizational commitment has a positive and significant effect on the successful implementation of accrual-based accounting in local governments.

The Influence of Competence of Human Resources, Quality of Information Technology and Organizational Commitment on the Successful Implementation of Accrual-Based Accounting

The results of this study indicate that the competence of human resources, the quality of information technology and organizational commitment simultaneously have a positive and significant effect on the successful implementation of accrual-based accounting in local governments. This can be interpreted that the competence of human resources, quality of information technology and high organizational commitment will encourage the successful implementation of accrual-based accounting. The successful implementation of accrual-based accounting is carried out based on Government Accounting 
Standards Statement No. 1 to No. 12. This is in line with the results of research conducted by Vezalin, et al. (2019), Dewi and Handayani (2018), Karyogis and Putra (2017), Arih, et al. (2017) and Davis (2010) which show that the competence of human resources, the quality of information technology and organizational commitment simultaneously affect the successful implementation of accrual-based accounting in local governments.

\section{Conclusions and suggestions}

\subsection{Conclusion}

Based on the results of the research and discussion that have been stated previously, the following conclusions can be drawn:

1. Competence of human resources has a positive and significant effect on the successful implementation of accrual-based accounting. This means that the higher the competence of human resources owned by the local government, the higher the successful implementation of accrual-based accounting.

2. The quality of information technology has a positive and significant effect on the successful implementation of accrualbased accounting. This means that the higher the quality of existing information technology or used by local governments, the higher the successful implementation of accrual-based accounting.

3. Organizational commitment has a positive and significant effect on the successful implementation of accrual-based accounting. This means that the higher the organizational commitment to the local government, the higher the successful implementation of accrual-based accounting.

4. Competence of human resources, quality of information technology and organizational commitment simultaneously have a positive and significant effect on the successful implementation of accrual-based accounting. This means that the higher the competence of human resources, and the better the quality of information technology used and the high organizational commitment to local governments, the higher the successful implementation of accrual-based accounting.

\subsection{Suggestion}

Based on the results of the research conducted, the researchers can provide the following suggestions:

1. The results of this study indicate that the quality of information technology has a positive and significant effect on the successful implementation of accrual-based accounting, which means that the quality of information technology is an important factor in supporting the success of accrual-based accounting implementation, but the average value of this variable indicator is the lowest value among other variables. So it is hoped that local governments will pay more attention to the quality of their information technology so that the preparation of financial reports can be done better.

2. For further researchers who are interested in researching the same problem, it is better to examine other variables that affect the successful implementation of accrual-based accounting such as communication, leadership style, regulation, and internal control system.

\section{References}

Adventana, G. A. \& Kurniawan, H. (2013). Analysis of Factors Influencing the DIY Provincial Government in Implementing Accrual-Based Government Accounting Standards According to Government Regulation No. 71 of 2010. Journal of the Faculty of Economics Atma Jaya Yogyakarta, 4(1).

Agyemang, J. K. (2017). Factors Affecting the Implementation of Accrual-Based International Public Sector Accounting Standards (AIPSAS) in Ghana. Texila International Journal of Management, 3(2).

Antipova, T., \& Bourmistrov, A. (2013). Is Russian Public Sector Accounting in the Process of Modernization? An Analysis of Accounting Reforms in Russia. Financial Accountability and Management, 29(4), 442-478.

Arif, R. (2020). Factors Affecting the Implementation of Accrual-Based Government Accounting Standards (Empirical Studies in Lamongan Regency Government). Media Mahardhika, 18(3), 378-386.

Arih, T.N., Rahayu, S. \& Nurbaiti, A. (2017). Analysis of Factors Affecting The Implementation of Accrual Based Governmental Standards In Bandung City Government. Indonesian Journal of Management, 17(1), 67-78.

Azman, (2015). Analysis of Organizational Commitment, Readiness of Human Resources, Infrastructure and Information Systems in Applying Accrual-Based Government Accounting Standards (Study on the Meranti Islands Regency Government). SOROT Journal, University of Riau, 10(1).

Azmi, A. H., \& Mohamed, N. (2014). Readiness of Malaysian Public Sector Employees in Moving Towards Accrual Accounting for Improve Accountability: The case of Ministry of Education (MOE). Procedia - Social and Behavioral Sciences, 164, 106-111.

Biswas, R.M., Rahman, M.S. \& Rahman, A. M. (2015). Effectiveness of Accrual Basis Accounting As Compared To Cash Basis Accounting In Financial Reporting. International Journal Of Multidisciplinary Research and Development, 2(10), 467-473. 
Christiaens, J. (1999). Financial Accounting Reform in Flemish Municipalities: an Empirical Study of Implementation and Annual Financial Reports. European Accounting Review, 8(4), 803-823.

Christiaens, J., Reyniers, B. Rollé, C. (2010). Impact of IPSAS on Reforming Governmental Financial Information Systems: A Comparative Study. International Review of Administrative Sciences, 76(3), 537- 554.

Davis, N. (2010). Accrual Accounting and the Australian Public Sector - A Legitimation Explanation. Australasian Accounting Business and Finance Journal, 4(2), 61-78.

Dewi, L. D.S., Purnamawati, I. G. A. \& Herawati, N. T. (2017). The Effect of Quality Human Resources, Organizational Commitment, and Internal Control System on the Successful Implementation of Accrual-Based Accounting Standards (Empirical Study on SKPD Bangil Regency). e-Journal S1 Ak Ganesha University of Education, 7(1).

Dewi, N.C. \& Handayani, N. (2018). Factors Affecting the Effectiveness of Implementing Accrual-Based Government Accounting Standards. Journal of Accounting Science and Research, 7(3), 1-22.

Fuchs, S., Bergmann, A. dan Brusca, S. (2015). The Short-term Impact of Modern Accrual Accounting Systems: Cross Sectional Evidence from Switzerland In Comparative International Governmental Accounting Research. University of Malta, Valeta.

Grandis, F.G. \& Mattei, G. (2012). Is There a Specific Accrual Basis Standard For The Public Sector? Theoretical Analysis and Harmonization of Italian Government Accounting. Journal of Accounting, (1), 27-37.

Halim, A., \& Kusufi, S. (2012). Theory, Concepts, and Applications of Public Sector Accounting, from Budgets to Financial Statements from Government to Places of Worship. Salemba Empat: Jakarta.

Hasibuan, R.P.S. (2021). Quality Commitment as a Benchmark in the Successful Implementation of Accrual-Based Government Accounting Standards. Journal of Business \& Public Accounting, 11(2), 59-69.

International Public Sector Accounting Standards Board. (2011). Transition to the Accrual Basis of Accounting: Guidance for Public Sector Entities, Study 14. Third Edition, IFAC. New York, USA.

Jalardi, E.Q. \& Riharjo, I.B. (2016). Factors Affecting the Effectiveness of Implementing Accrual-Based Government Accounting Standards. Journal of Science and Accounting Research STESIA Surabaya, 5(11).

Jantong, A. (2017). Determinants of Readiness to Implement Accrual-Based Government Accounting Standards in Manggarai, East Nusa Tenggara. Matra Pembaruan Brawijaya University Malang, 1(1), 109-119.

Jantong, A., Nurkholis, \& Roekhudin. (2018). Factors Affecting Readiness to Implement Accrual-Based Government Accounting Standards in Local Governments. Journal of Business and Management, 5(2), 158-169.

Kamemy, L., Enni S., \& Al Azhar. (2017). Analysis of Factors Affecting the Implementation of Accrual Accounting in the Riau Provincial Government (Empirical Study on SKPD Riau Province). Online Journal of Students of the Faculty of Economics, University of Riau, 4(1), 1.108-1.121.

Kara, E., \& Kilic, Y. (2011). Accounting Recording System On Accrual Basis At Local Authorities In Turkey: An Application In Gaziantep Local Municipality. International Journal of Business and Social Science, 2(15).

Karyogis, K.N. \& Putra, I.M.P.D. (2017). Analysis of Factors Affecting the Implementation of Accrual-Based Government Accounting Standards in Bangli Regency. Udayana University Accounting E-Journal, 20(1), $555-584$.

Kristiawati, E. 2015. Factors Affecting the Successful Implementation of Accrual-Based Accounting in West Kalimantan Regional Government. Accountability, 8(3), 171-190.

Kristyono, J., Riharjo, K. \& Andini, R. (2013). Factors Affecting the Successful Implementation of Regional Finance in accordance with Government Regulation No. 71/2010 (Study at the Semarang City Education Office in 2012/2013). Accounting Journal, 2 (1).

Leppänen, P., \& Näsi, S. (2015). Accrual Accounting in Finnish Local Governments - Source of Comparable Financial Information or a Field of Creative Accounting? In Comparative International Goverment Accounting Research. University of Mlta, Valeta.

Mahmudi. (2011). Regional Financial Management. Jakarta: Erlangga.

Marsdenia \& Arthaingan, M.A.H. (2016). Factors Affecting the Successful Implementation of Accrual-Based Government Accounting Standards: An Empirical Study on Bogor City Government. Indonesian Vocational Journal, 4(2), 66-92.

Matekele, C. K. and Komba, G. V. (2019). Factors Influencing Implementation of Accrual Based International Public Sector Accounting Standards in Tanzanian Local Government Authorities. Asian Journal of Economics, Business and Accounting, 13(3), 1-25.

McKendrick, J. (2007). Modernization of the Public Accounting Systems in Central and Eastern European Countries: the Case of Romania. International Public Management Review, 8(1), 168-185.

Minister of Finance of the Republic of Indonesia, Government Regulation Number 71 of 2010 concerning Government Accounting Standards. (www.jdih.Kemenkeu.go.id). Retrieved 20 September 2019.

Norfalizah. (2015). Analysis of Government Readiness Factors in Applying Accrual-Based Government Accounting (Case Study on SKPD of Rokan Hilir Regency. Jom FEKON, Riau University, Pekanbaru, 2(2).

Osborne, D., \& Gaebler, T. (1992). Reinventing Government: How the Entrepreneurial Spirit is Transforming the Public Sector. Penguin, London/New York, NY.

Phuong-Nguyen, T. T., Hai-Phan, T., Tung-Nguyen, T., \& Tien-Vo, T.T. (2020). Factors affecting accrual accounting reform and transparency of performance in the public sector in Vietnam. Problems and Perspectives in Management, $18(2), 180-193$.

Pratiwi, P.A.S.A., Musmini, L.S., \& Sujana, E. (2013). The Effect of Knowledge of Regional Financial Management, Personal Background, and Commitment to the Ability of Regional Apparatus Work Units in the Preparation of Regional 
Financial Reports. e-Journal of S1 Ak Ganeshaha University of Education, 2(1).

Putra, I.W.G.Y.D., \& Ariyanto, D. (2015). Factors Influencing the Implementation of Accrual-Based Government Accounting Standards. Udayana University Accounting E-Journal, 13(1), 14-32.

Rahmansah. (2012). Factors Affecting the Successful Implementation of Government Regulation Number 71 of 2010 in the Provincial Government of Bangka Belitung. Thesis. Terbuka University Postgraduate Program. Jakarta.

Robbins, S. P. (2008). Organization Behavior, Concepts Controversies, Application. Englewood Cliffs, A Somon and Chuster Company. New Jersey.

Robinson, M. (1998). Accrual Accounting and the Efficiency of the Core Public Sector. Financial Accountability and Management, 14(1), 21-37.

Safitri, D. (2017). Factors Influencing the Implementation of Accrual-Based Government Accounting Standards (Study on Bengkalis Regency Government SKPD). Journal of Accounting, 5(2), 174-189.

Sampel, I.F., Kalangi, L. \& Runtu, T. (2014). Analysis of Readiness to Implement Accrual Basis Government Accounting Standards in Manado City Government. EMBA Journal, 3(1).

Satrio, M.D., Yuhertiana, I. \& Hamzah, A. (2016). Implementation of Accrual-Based Government Accounting Standards in Jombang Regency. Journal of Accounting and Finance, 18(1), 59-70.

Slamet, B. (2016). Factors Affecting the Successful Implementation of Accrual-Based Government Accounting (Case Study in Bekasi City Government). JIAFE (Scientific Journal of Accounting, Faculty of Economics), 2(2), 1-15.

Sudaryati, D., \& Heriningsih, S. (2014). The Influence of Human Resource Competence on Accrual Accounting Implementation with Supporting Devices as Moderating Variables (Empirical Study on Yogyakarta City Government). Optimum Journal, 4(2).

Supra, D. (2016). The Effect of Education Level, Training and Quality of Information Technology on the Implementation of Accrual-Based Government Accounting Standards in the Musi Banyuasin Regency Government. Journal of Accounting Sekayu Polytechnic (ACSY), 5(2), 9-23.

Suryanto. (2017). A Review of Implementation of Accrual-Based Government Accounting in Indonesia. AdBispreneur Journal, 2(3), 217-226.

Tengku, A. (2015). Analysis of Organizational Commitment, Readiness of Human Resources, Infrastructure and Information Systems in Applying Accrual-Based Government Accounting Standards: A Study on the Meranti Islands Regency Government. SOROT Journal, University of Riau, 10(1).

The Supreme Audit Agency of the Republic of Indonesia, 2019. Results of the First Semester Examination of 2019. (www.bpk.go.id). Retrieved 15 December 2019.

Vezalin, F., Sartika, D. \& Ilyas, A. (2019). Implementation of Accrual-Based Government Accounting Standards (Case Study in Padang City BPKAD). Dharma Andalas Journal of Economics and Business, 21(2), 165-177.

Widyastuti, N. M., Ari, E.S. \& Adiputra, I.M.P. (2015). Analysis of Regional Government Readiness in Applying AccrualBased Government Accounting Standards in Gianyar Regency. e-Journal S1 Ak Ganesha University of Education, 3(1).

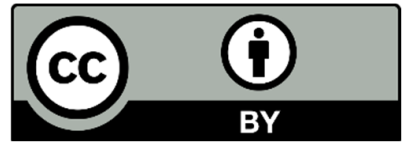

(C) 2022 by the authors; licensee Growing Science, Canada. This is an open access article distributed under the terms and conditions of the Creative Commons Attribution (CC-BY) license (http://creativecommons.org/licenses/by/4.0/). 